\title{
Erratum to: Surface Selective Oxidation of Sn-Added CMnSi TRIP Steel
}

\author{
LAWRENCE CHO, EUN JUNG SEO, GEUN SU JUNG, DONG WOO SUH, \\ and BRUNO C. DE COOMAN
}

DOI: $10.1007 / \mathrm{s} 11661-016-3369-\mathrm{y}$

(C) The Minerals, Metals \& Materials Society and ASM International 2016

\section{Erratum to: METALLURGICAL AND MATERIALS \\ TRANSACTIONS A \\ DOI: $10.1007 / \mathrm{s} 11661-016-3331-\mathrm{z}$}

IN the original article there are several errors in Table IV. The corrected Table IV is given below.

Table IV. Calculated Mass Fractions of the $\mathrm{MnO}$ and $\mathrm{SiO}_{2}$ Which are Predicted to Form on the Surface of a 1.6 wt Pet Mn-1.5 wt Pet Si Steel After Isothermal Annealing at $1093 \mathrm{~K}$ $\left(820{ }^{\circ} \mathrm{C}\right)$ for $47 \mathrm{~s}$

\begin{tabular}{llcc}
\hline & \multicolumn{2}{c}{ Mass Fractions $(\mathrm{ppm})$} & \multirow{2}{*}{$\begin{array}{c}\text { Mn/Si Mass } \\
\text { Ratio at the } \\
\text { Surface }\end{array}$} \\
\cline { 2 - 3 } Dew Point $\left({ }^{\circ} \mathrm{C}\right)$ & $\mathrm{MnO}$ & $\mathrm{SiO}_{2}$ & \\
\hline-70 & 0 & $2.88 \times 10^{4}$ & 0.0155 \\
-60 & $4.89 \times 10^{3}$ & $3.19 \times 10^{4}$ & 0.2110 \\
-10 & $2.06 \times 10^{4}$ & $3.21 \times 10^{4}$ & 1.2600 \\
\hline
\end{tabular}

The calculated $\mathrm{Mn} / \mathrm{Si}$ mass ratios at the surface are also listed.

LAWRENCE CHO, Post-Doctoral Researcher, EUN JUNG SEO, Graduate Student, and BRUNO C. DE COOMAN, Professor and Director, are with the Materials Design Laboratory, Graduate Institute of Ferrous Technology, Pohang University of Science and Technology, Pohang 790-784, South Korea. Contact e-mail: decooman@postech.ac.kr GEUN SU JUNG, Graduate Student, and DONG WOO SUH, Professor, are with the Computational Metallurgy Laboratory, Graduate Institute of Ferrous Technology, Pohang University of Science and Technology, Pohang 790-784, South Korea.

The online version of the original article can be found under doi: 10.1007/s11661-016-3331-z.

Article published online February 24, 2016 